\section{Nanostructure and Surface \\ Characteristic of Electrospun \\ Carbon Black/PVDF Copolymer \\ Nanocomposite}

Muhamad NASIR - Research Unit for Clean Technology,

Indonesian Institute of Sciences (LIPI), Indonesia - mnasir71@yahoo.com

RANA IDA SUGATRI - Research Unit for Clean Technology,

Indonesian Institute of Sciences (LIPI), Indonesia

PutrI Putih Puspa ASRI - Research Unit for Clean Technology,

Indonesian Institute of Sciences (LIPI), Indonesia

FITRI DARA - Research Unit for Clean Technology,

Indonesian Institute of Sciences (LIPI), Indonesia

ARDENISWAN - Research Unit for Clean Technology,

Indonesian Institute of Sciences (LIPI), Indonesia

Érkezett: 2018. 07. 24. - Received: 24. 07. 2018. - https://doi.org/10.14382/epitoanyag-jsbcm.2018.36

\section{Abstract}

Carbon black/PVDF copolymer (CB/PVDF copolymer) nanofiber composite has been synthesized by electrospinning process. Nanostructure and surface property of CB/PVDF copolymer were studied by using Scanning Electron Microscopy (SEM), Fourier Transform Infrared Spectroscopy (FTIR), X-ray Diffraction (XRD) and water contact angle (WCA). Nanofiber composite has smooth surface morphology without bead on nanofiber string. Increase of CB content in nanofiber composite decreased diameter of nanofiber size. Range of average nanofiber diameter was from 405.2 and $421.3 \mathrm{~nm}$ where it depended on CB content in nanofiber composite. FTIR and XRD analysis showed that structure of PVDF copolymer in nanofiber composite had a dominant $\beta$ phase crystal structure. The $\beta$ phase was showed and confirmed by vibration band peak at $838.55 \mathrm{~cm}^{-1}$ of IR spectrum and $2 \theta=20.44^{\circ}$ of XRD. Presence of CB in nanofiber composite also influenced WCA and water spreading on nanofiber composite. WCA of pristine PVDF copolymer, CB/PVDF copolymer nanofiber with 1\% CB, and CB/PVDF copolymer with 5\% CB were 113.8 , $105.2,117.3^{\circ}$. From this result showed that nanostructure and surface characteristic can be adjusted and controlled by presence of $\mathrm{CB}$ in nanofiber composite. This result has potential application for air filtration to solve air pollution issued.

Keywords: CB/PVDF copolymer nanofiber composite, carbon black, nanostructure, electrospinning, water contact angle of nanofiber composite

Kulcsszavak: CB/PVDF kopolimer nanoszál kompozit, szén fekete, nanoszerkezet, elektroszálképzés, víz nedvesítési szöge nanoszál kompoziton

\section{Introduction}

Nanofiber, fabricated by electrospinning, has great potential to be used in many environmental applications. The main advantage of this process is the relative quick and simple way to fabricate a variety of materials into nanofiber structure [1]. Besides, the high surface-to-volume ratio, large porosity (up to over $80 \%$ ) and adjustable functionality are more effective than conventional non-woven and polymeric membranes in particulate separation and liquid filtration [2].

Poly(vinylidene fluoride) (PVDF) nanofiber and poly(vinylidene) fluoride copolymer are the polymer materials which easily synthesized by electrospinning process. Excellent resistance towards harsh chemicals, piezoelectricity, flexibility, durability, lightweight, and relatively low acoustic impedance properties [3-5] considered PVDF nanofiber to be used in some applications such as membrane separator of secondary Li-ion battery [6-8], supercapacitor [9-10], sensing element [11-13] and air filtration [14-16].
Dr. Eng. Muhamad NASIR He has research interest in nanomaterials and nanoengineering fields especially in nanofiber,

nanoparticle such metal, metal oxide, and nanocarbon, nanocomposite, electrospinning and membrane process for various applications. He finished his PhD in Tokyo Institute of Technology, Japan. After that he took postdoctoral in Kyoto Institute of Technology, Japan. Now he is head of environmental nanotechnology research group in Research Unit for Clean Technology, Indonesian Institute of Sciences (LIPI).

Rana Ida SUGATR She obtained her bachelor's degree from University of Jenderal Achmad Yani, Indonesia in 2016. She is currently a research assistant under the supervision of Dr. Eng. Muhamad Nasir at Research Unit for Clean Technology, Indonesian Institute of Sciences. She joined in a team that focuses on the development of nanofiber and nanoparticle as main materials to solve environmental problems. In the laboratory, she showed interests in a synthesis nanofiber using electrospinning process and their application as membrane filtration

Putri Putih Puspa ASRI She received her bachelor degree in chemistry from Jenderal Achmad Yani University, Cimahi, Indonesia In 2016. She worked as Research Assistant and was doing some research related to nanotechnology topic under supervision of Dr. Eng. Muhamad Nasir. Her research interests are synthesis, nanomaterial composite for battery application, thermal and spectroscopy characterization for nanomaterial composite, and nanomaterial for green and sustainable technology.

Dr. Fitri DARA

Researcher at Research Unit for Clean Technology, Indonesian Institute of Sciences. She finished her Doctoral Programme in 2017 from Chemistry Department, Institut Teknologi

Bandung, Indonesia. Her research interest is qualitatively and quantitatively assess Nanoparticle (NP) under environmentally relevant conditions, reflecting amongst others not only realistic NP concentrations, environmental conditions but also reaction and residence times.

ARDENISWAN He received his master degree in environmental engineering, Bandung Institute of Technology. His research interest is in the field of hazardous waste and environmental monitoring such as air and water pollution.

PVDF has dipole moments due to the polar C-F bond which distribute along the fiber axis. It causes the electrostatic attractive forces integrate along the length of the fiber segments. This integration strengthens the electric field projected from the fibers $[15,17]$. The electric charge which takes place between filter media and dust particles makes PVDF nanofiber is capable for capturing particles (charged and uncharged aerosols) effectively in air filtration application [14-16, 1819]. The fibers with small diameter enhance the van der Walls attractive force between nanofiber and particle [14] then trap particles among the polymer matrix [16]

The unique electrospinning process offers opportunities to fine tune the surface functionality through polymer chemistry, 
blending and nanofiller incorporation during the process [2]. New approaches in a modification of nanofiber were reported by many researchers which have been incorporating nanoparticle in solution polymer system for fabricating nanofiber composite.

It has been over one decade that carbon black (CB) nanoparticle became one of the interesting materials to modify polymer nanofiber due to small particle size (high surface area), aggregation behavior, low cost and conductive property [20-21] Those properties make CB has usability as an adsorbent material [22]. Islam et al [23] reported that CB is the most effective adsorbent material than extruded activated carbon and granular activated carbon. In nanofiber system, the presence of $\mathrm{CB}$ in polyurethane (PU) [20] and polyaniline (PANI) [24] nanofiber composite increased the fiber web strength and electrical conductivity. However, it decreased significantly when CB incorporated in PEO system [25].

As much as we know that no other researchers reported the effect of incorporating CB in pristine PVDF copolymer solution to synthesize nanofiber using electrospinning. In this work, we used some variation of the amount of $\mathrm{CB}$ which incorporated into PVDF copolymer to produce nanofiber composite. We concerned in basic concept including effect of the filler content on the fiber morphology, the bond structure of the nanofiber composite, the crystallinity and the hydrophilicity. These results will support usability of CB/PVDF copolymer nanofiber composite to improve PVDF nanofiber function as air filtration. We suggested this nanofiber composite not only trap particulate matter, but also adsorb chemical pollutant in the air. Increasing the web strength and electrical conductivity of CB/PVDF copolymer nanofiber composite are expected can improve their ability to trap particulate matter more easily.

\section{Experimental}

\subsection{Materials}

Poly(vinylidene fluoride) (PVDF) copolymer which was used in this work is poly(vinylidene fluoride-co-hexafluoropropene) (PVDF-HFP). It was purchased from Arkema Inc. U.S.A. The N,N-dimethylacemide (DMAc) from Merck was used as solvent for preparation of polymer solution. Carbon black (Dashblack HAF N330) was obtained from OCI Company Ltd. and used as nanoparticle which incorporated into polymer solution.

\subsection{Nanofiber preparation}

A $24 \%(w / v)$ cPVDF solution was prepared by dissolving $2.4 \mathrm{~g}$ cPVDF powder in $10 \mathrm{~mL}$ DMAc. It was stirred at room temperature for $5 \mathrm{~h}$. CB was added to the cPVDF solution with variation concentration 0,1 , and $5 \%(\mathrm{w} / \mathrm{v})$ for pristine PVDF, CB1/PVDF copolymer and CB5/PVDF copolymer, respectively, then stirred for $12 \mathrm{~h}$. The composite solution was spun into nanofiber using electrospinning with parameters 22 $\mathrm{kV}, 13 \mathrm{~cm}$, and $0.004 \mathrm{~mL} / \mathrm{min}$ for $2 \mathrm{~h}$.

\subsection{Characterization}

Surface morphology of nanofiber was analyzed by Scanning Electron Microscopy (SEM) SEMSU3500. Fourier Transform
Infrared Spectroscopy (FTIR) Nicolet iS5 ATR iD5 Thermo Scientific was used for analysis of interaction between PVDF and carbon black in nanofiber composite. Crystallinity between pristine PVDF nanofiber and its composite was analyzed by XRD Shimadzu 7000. Water contact angle was measured by drop shape method and calculated by the equation:

$\frac{\theta}{2}=\tan ^{-1}\left(\frac{\mathrm{h}}{\mathrm{d}}\right)$ with $\theta=$ contact angle, $\mathrm{d}=$ diameter, $\mathrm{h}=$ height.

\section{Results and discussion}

\subsection{Morphological characteristics and fiber diameters}

Incorporated CB into PVDF copolymer nanofiber system gives effect onto morphology and diameter of nanofiber. The amount of $\mathrm{CB}$ was added into polymer solution is 0,1 , and $5 \%$ $(\mathrm{w} / \mathrm{v})$. Fig. 1 shows that pristine and composite of nanofibers have smooth morphology without bead on nanofiber string. Increase of $\mathrm{CB}$ content in $\mathrm{CB} / \mathrm{PVDF}$ copolymer nanofiber composite results decreasing diameter of nanofiber. Diameter of pristine PVDF copolymer nanofiber is $599.5 \mathrm{~nm}$ then changes to 405.2 and $421.3 \mathrm{~nm}$ after adding carbon black 1 and $5 \%(w / v)$, respectively. The diameter of CB/PVDF copolymer nanofiber composite tends to decrease was caused by the tendency of CB to absorb the solvent. Evaporation of solvent in composite polymer solution can be slower than pristine polymer during the fiber formation $[20,26]$. Besides, the conductivity of $\mathrm{CB}$ in composite polymer solution also caused diameter of $\mathrm{CB} / \mathrm{PVDF}$ copolymer nanofiber is smaller than pristine PVDF copolymer [27-28]. In CB5/PVDF copolymer composite nanofiber, the diameter is larger than CB1/PVDF copolymer. It suggested the amount of CB 5\% (w/v) attributed to form agglomeration of nanoparticle. The agglomeration of $\mathrm{CB}$ is apparent on the fiber surface clearly, see Fig. 1.c.

\subsection{Infrared spectrum}

The bond structure and interaction between CB and PVDF copolymer in nanofiber composite is shown by Fig. 2 .

In the IR spectrum of PVDF copolymer, crystalline $\beta$ phase peak at $839.23 \mathrm{~cm}^{-1}$ indicated rocking vibration of $\mathrm{CH}_{2}$ group. The presence of $\mathrm{CB}$ in composite nanofiber caused shifting peak at 838.55 and $834.62 \mathrm{~cm}^{-1}$ for CB1/PVDF copolymer and CB5/PVDF copolymer, respectively. The $\mathrm{CF}_{2}$ symmetrical stretching was shown at $1400.27,1175.09$, and $1072.76 \mathrm{~cm}^{-1}$. Incorporated $\mathrm{CB}$ in $\mathrm{CB} / \mathrm{PVDF}$ copolymer nanofiber composite caused shifting peak at $\mathrm{CF}_{2}$ function group such as 1399.30 , 1171 , and $1071.99 \mathrm{~cm}^{-1}$ for CB1/PVDF copolymer and 1396.61 , 1164.68 , and $1062.16 \mathrm{~cm}^{-1}$ for CB5/PVDF copolymer. The $1274.58 \mathrm{~cm}^{-1}$ is a peak for CF stretching vibration. Decreasing band intensity at about $1274 \mathrm{~cm}^{-1}$ in $\mathrm{CB} / \mathrm{PVDF}$ copolymer can be caused by interaction between function group of $\mathrm{CB}$ and CF of PVDF. The $876.81 \mathrm{~cm}^{-1}$ is identical for $\mathrm{CH}_{2}$ of PVDF. It shifted to 875.71 and 871.17 after added CB 1 and 5\% (w/v), respectively. Band peaks at around $1160-900 \mathrm{~cm}^{-1}$ and $800-600$ $\mathrm{cm}^{-1}$ of $\mathrm{CB} / \mathrm{PVDF}$ copolymer nanofiber composite are broader than pristine PVDF copolymer nanofiber due to dominant effect from increasing amount of $\mathrm{CB}$ in nanofiber composite. The $\mathrm{C} \equiv \mathrm{C}$ bonding and $\mathrm{CH}_{3}-\mathrm{O}$ - at 2114.04 and $993.36 \mathrm{~cm}^{-1}$ are characteristics of $\mathrm{CB}$ function groups. 

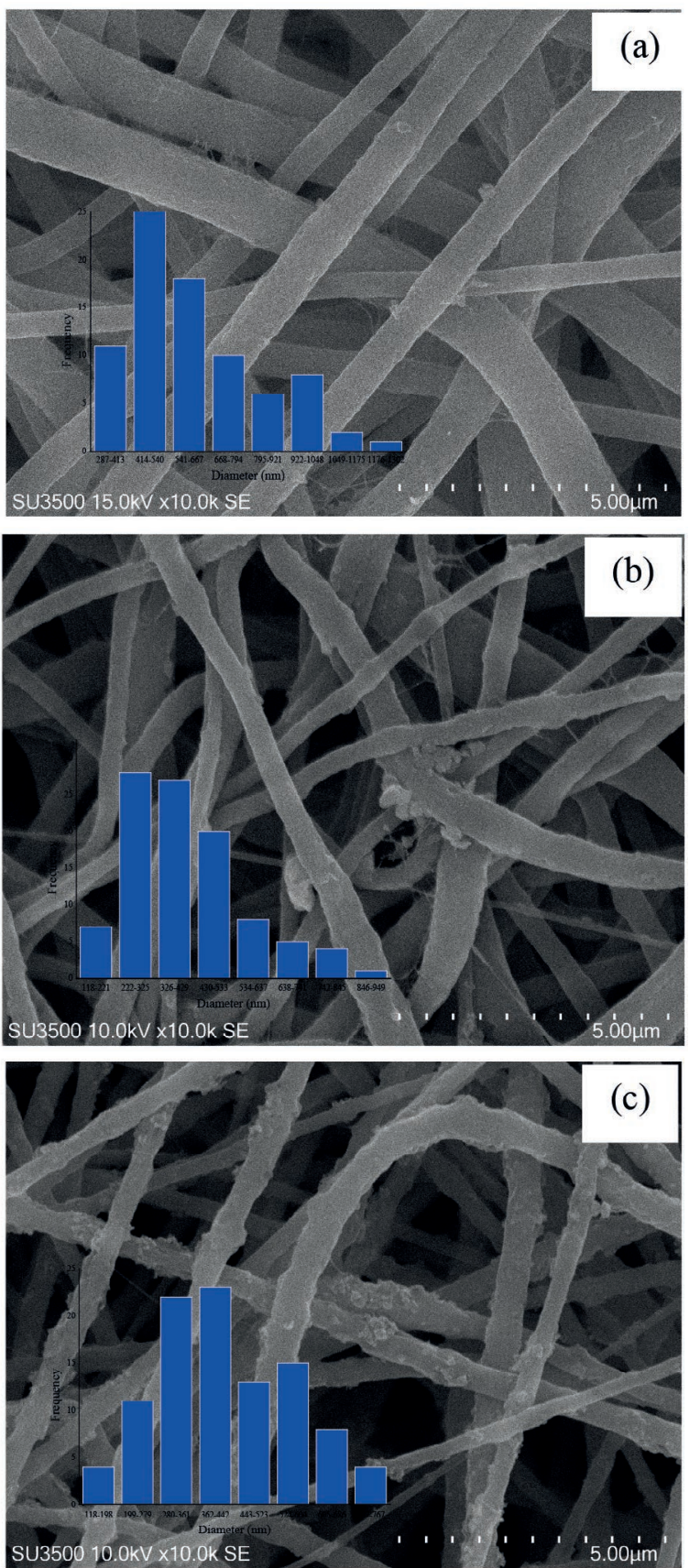

Fig. 1 SEM images of CB/PVDF copolymer nanofiber with various amount of $C B$ (a) pristine PVDF copolymer, (b) $1 \%(w / v)$ and (c) $5 \%(w / v)$

1. ábra Elektronmikroszkópos felvételek; CB/PVDF kopolimer nanoszál különbözó CB adagolással (a) kiindulási PVDF kopolimer, (b) 1\% (w/v) és (c) 5\% (w/v)

\subsection{Crystallinity}

$\mathrm{X}$-ray diffraction $(\mathrm{XRD})$ pattern confirms the existence and effect of CB in nanofiber composite. Fig. 3 shows characteristic peak at $2 \theta=20.44^{\circ}$ for pristine PVDF copolymer nanofiber, $20.06^{\circ}$ for $\mathrm{CB} 1 / \mathrm{PVDF}$ copolymer and $20.88^{\circ}$ for CB5/PVDF copolymer. Those peaks show strong peak of piezoelectric crystal $\beta$-phase structure of PVDF copolymer. The CB which incorporated in PVDF copolymer nanofiber gives effect on crystallinity of composite. $\mathrm{CB}$ acts as the nucleation agent in polymer matrix which affecting the crystallization process in the formation of PVDF copolymer nanofiber [29].
Incorporating $\mathrm{CB}$ in PVDF copolymer nanofiber decreases the crystallinity. The pristine PVDF copolymer nanofiber has $49.84 \%$ and decreases to 42.73 and $48.49 \%$ for adding CB 1 and $5 \%(\mathrm{w} / \mathrm{v})$, respectively. The crystalline structure of the $\mathrm{CB} /$ PVDF copolymer may arise from the cooperative orientation of the CB and PVDF copolymer chains along the fiber axis to facilitate the nucleation of highly oriented chains crystallites at the interface [30]. The amount and type of nanoparticle can result difference crystallinity [29-31].

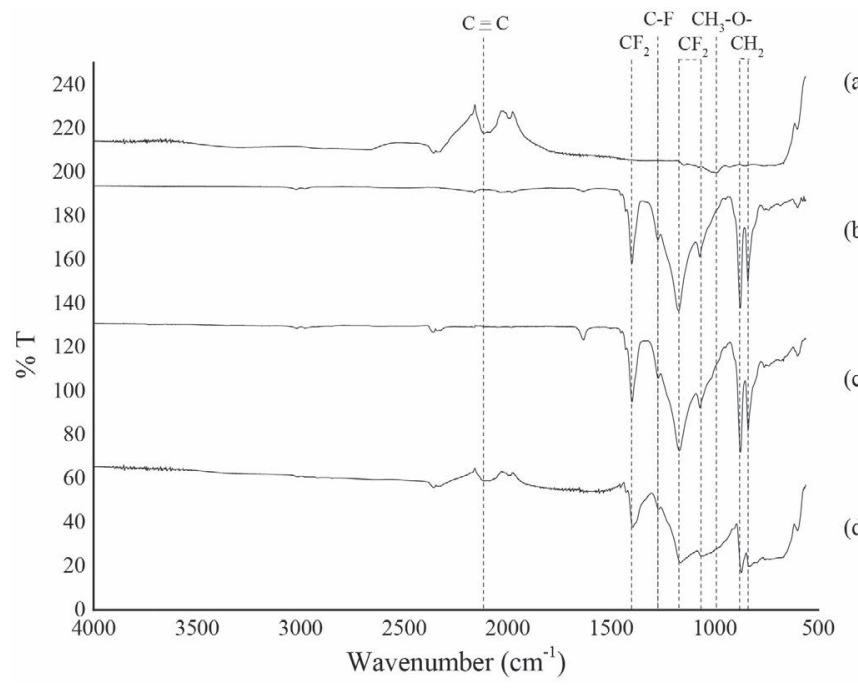

Fig. 2 FTIR spectrum of CB/PVDF copolymer nanofiber composite (a) $C B$ nanoparticle, (b) pristine PVDF copolymer, (c) CB1/PVDF copolymer, and (d) CB5/PVDF copolymer

2. ábra FTIR spektrumok; $C B / P V D F$ kopolimer nanoszál kompozit (a) $C B$ nanorészecske, (b) kiindulási PVDF kopolimer, (c) CB1/PVDF kopolimer, és (d) CB5/PVDF kopolimer

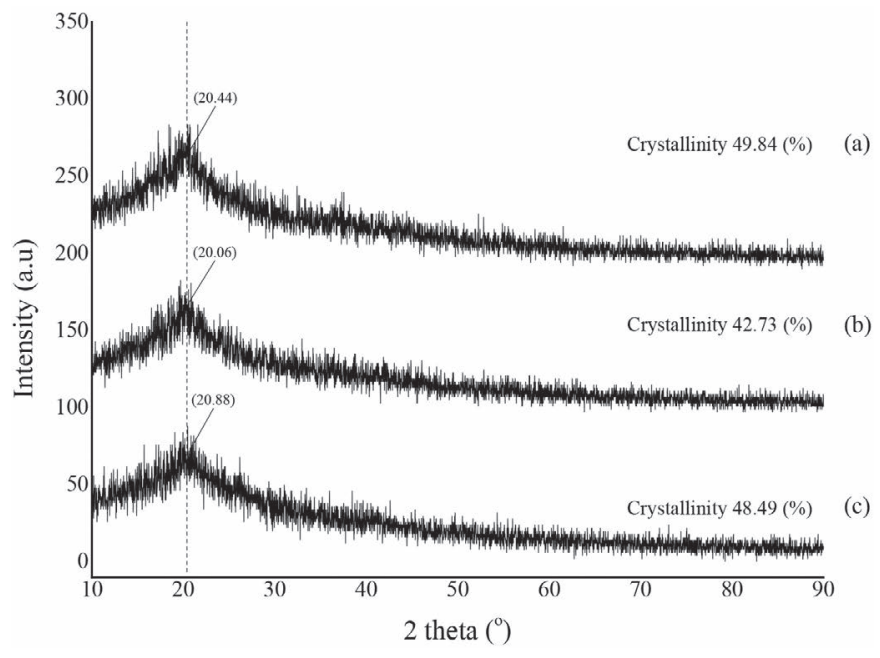

Fig. 3 XRD spectrum of nanofiber composite (a) pristine PVDF copolymer, (b) CB1/ $P V D F$ copolymer, and (c) CB5/PVDF copolymer

3. ábra Kompozit nanoszál röntgendiffraktogramok (a) kiindulási PVDF kopolimer (b) CB1/PVDF kopolimer, és (c) CB5/PVDF kopolimer

\subsection{Hydrophobicity}

The hydrophobicity of the nanofiber is analyzed by its value of water contact angle. The amount of $\mathrm{CB}$ which incorporated in $\mathrm{CB} / \mathrm{PVDF}$ copolymer nanofiber composite gives effect to contact angle value. Pristine PVDF copolymer nanofiber has $113.8^{\circ}$ then decreases to 105.2 for CB1/PVDF copolymer, but increases to $117.3^{\circ}$ for CB5/PVDF copolymer. 
Many pores of CB have ability to absorb liquid matter. In Figs. 1 and 5, CB incorporated well inside of CB1/PVDF copolymer nanofiber. When water droplet contacted with surface nanofiber, it is not only interacts with C-F of PVDF copolymer but also with function groups and pores of $\mathrm{CB}$. It suggested contact angle value of water droplet is smaller than pristine PVDF copolymer nanofiber. Unlike CB5/PVDF copolymer, $\mathrm{CB}$ made formation of agglomeration and apparent on surface of nanofiber. In this case, the surface roughness plays a role in the formation of higher contact angle.

Fig. 4 shows the spreading time of water droplet on CB/PVDF copolymer composite nanofiber. After 130 and 240 minutes, water droplet on CB5/PVDF copolymer composite nanofiber is faster to spread than pristine PVDF copolymer and CB1/ PVDF copolymer regularly. In that time, water droplet has contacted with $\mathrm{CB}$ surface then $\mathrm{CB}$ can easily absorb water.

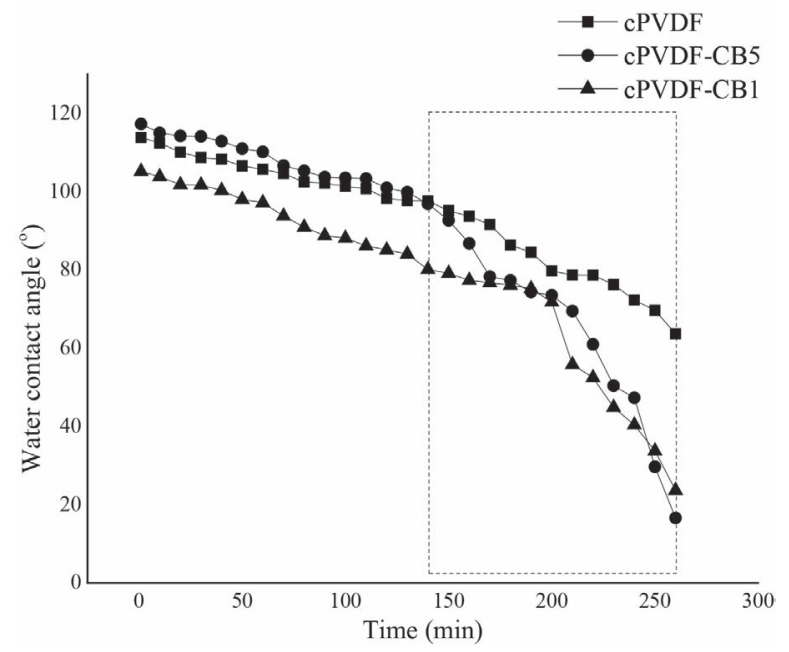

Fig. 4 The spreading time of water droplet on $C B / P V D F$ copolymer nanofiber composite

4. ábra Vizcsepp terjedési ideje CB/PVDF kopolimer nanoszál kompoziton

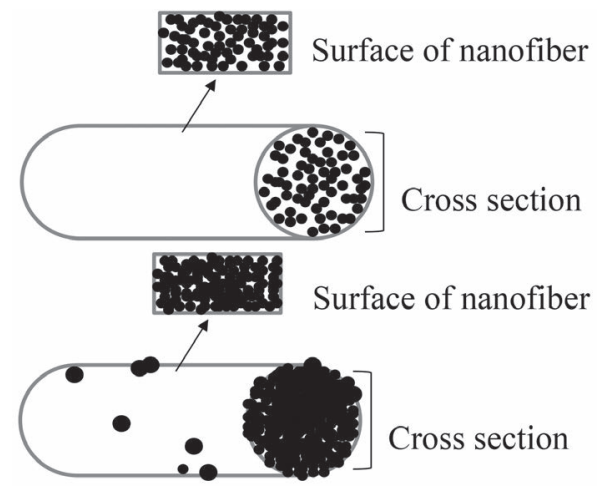

Fig. 5 Illustration of $C B$ incorporated in $C B / P V D F$ copolymer nanofiber composite 5. ábra CB elegyedésének illusztrációja CB/PVDF kopolimer nanoszál kompozittal

\section{Conclusions}

PVDF copolymer nanofiber composite was successfully synthesized by electrospinning which incorporating $\mathrm{CB}$ into solution system. These results clearly demonstrate that $\mathrm{CB}$ has significant effect on nanostructure and surface characteristic. Their morphology showed that the presence of CB in PVDF copolymer nanofiber system decreases diameter of nanofiber nanocomposite. In 5\% (w/v) of CB in nanofiber composite, the agglomeration of nanoparticle is apparent in surface of nanofiber. Interaction between $\mathrm{CB}$ and PVDF was showed by shifting peak at $\mathrm{CF}_{2}$ and $\mathrm{CH}_{2}$ function groups and making band be broader than pristine PVDF copolymer. IR and XRD data confirm a dominant of $\beta$ phase crystal structure of PVDF copolymer. The presence of $\mathrm{CB}$ in nanofiber composite also decreases their crystallinity. Besides, the hydrophobicity of $\mathrm{CB} /$ PVDF copolymer nanofiber composite changes to $105.2^{\circ}$ and $117.3^{\circ}$ for adding 1 and 5\% (w/v) CB content, respectively, from $113.8^{\circ}$ of pristine PVDF copolymer. After 130 and 240 minutes, CB5/PVDF copolymer nanofiber composite is faster to spread than pristine PVDF copolymer and CB1/PVDF copolymer.

\section{References}

[1] Faccini, M. - Vaquero, C. - Amantia, D. (2012): Development of Protective Clothing against Nanoparticle Based on Electrospun Nanofibers, Journal of Nanomaterials, Vol. 2012, Article ID 892894, pp 1-9. https://doi.org/10.1155/2012/892894

[2] Yoon, K. - Hsiao, B. S. - Chu, B. (2008): Functional Nanofibers for Environmental Applications, Journal of Materials Chemistry, Vol. 18, pp 5326-5334. https://doi.org/10.1039/b804128h

[3] Kawai, H. (1969): The Piezoelectricity of Poly(Vinylidene Fluoride), Japanese Journal Applied Physics, Vol. 8, pp 975-976. http://doi.org/10.1143/JJAP.8.975

[4] Rao, S. S. - Sunar, M. (1994): Piezoelectricity and Its Use in Disturbance Sensing and Control of Flexible Structures: A Survey, Applied Mechanics Reviews, Vol. 47, pp 113-123. https://doi.org/10.1115/1.3111074

[5] Sheikh, F. A. - Zargar, M. A. - Tamboli, A. H. - Kim, H. (2016): A Super Hydrophilic Modification of Poly(Vinylidene Fluoride) (PVDF) Nanofibers: By In Situ Hydrothermal Approach, Applied Surface Science, Vol. 385, pp 417-425. https://doi.org/10.1016/j.apsusc.2016.05.111

[6] Choi, S. S. - Lee, Y. S. - Joo, C. W. - Lee, S. G. - Park, J. K. - Han, K. S. (2004): Electrospun PVDF Nanofiber Web as Polymer Electrolyte or Separator, Electrochimica Acta, Vol. 50, pp 339-343. https://doi.org/10.1016/j.electacta.2004.03.057

[7] Hwang, K. - Kwon, B. - Byun, H. (2011): Preparation of PVDF Nanofiber Membranes by Electrospinning and Their Use as Secondary Battery Separators, Journal of Membrane Science, Vol. 378, pp 111-116. https://doi.org/10.1016/j.memsci.2011.06.005

[8] Widiyandari, H. - Purwanto, A. - Widyanto, S. A. (2017): Polyvinilidine Fluoride (PVDF) Nanofiber Membrane for Li-Ion Rechargeable Battery Separator, Jurnal of Physics: Conference Series, Vol. 817, 012013, pp 1-6. https://doi.org/10.1088/1742-6596/817/1/012013

[9] Zhu, Z. - Tang, S. - Yuan, J. - Qin, X. - Deng, Y. - Qu, R. - Haarberg, G. M. (2016): Effects of Various Binders on Supercapacitor Performances, International Journal of Electrochemical Science, Vol. 11, pp 8270-8279. https://doi.org/10.20964/2016.10.04

[10] He, T. - Jia, R. - Lang, X. - Wu X. - Wang, Y. (2017): Preparation and Electrochemical Performance of PVDF Ultrafine Porous Fiber SeparatorCum-Electrolyte for Supercapacitor, Journal of The Electrochemical Society, Vol. 164, pp E379-E384. https://doi.org/10.1149/2.0631713jes

[11]Zampetti, W. - Bearzotti, A. - Macagnano, A. (2014): Flexible Piezoelectric Transducer Based on Electrospun PVDF Nanofibers for Sensing Applications, Procedia Engineering, Vol. 87, pp 1509-1512. https://doi.org/10.1016/j.proeng.2014.11.585

[12] Sengupta, D. - Kottapalli, A. G. P. - Chen, S. H. - Miao, J. M. - Kwok, C. Y. - Triantafyllou, M. S. - Warkiani, M. E. - Asadnia, M. (2017): Characterization of Single Polyvinylidene Fluoride (PVDF) Nanofiber for Flow Sensing Applications, American Institute of Physics Advances, Vol. 7, 105205, pp 1-7. https://doi.org/10.1063/1.4994968

[13] Parker, A. - Ueda, A. - Marvinney C. E. - Hagrove, S. K. - Williamns, F. - Mu, R. (2018): Structural and Thermal Treatment Evaluation of Electrospun PVDF Nanofibers for Sensors, Journal of Polymer Science and Applications, Vol. 2, 1000109, p 1-4. 
[14] Li, Z. - Kang, W. - Zhao, H. - Hu, M. - Ju, J. - Deng, N. - Cheng, B. (2016): Fabrication of A Polyvinylidene Fluoride Tree-Like Nanofiber Web for Ultra High Performance Air Filtration, Royal Society of Chemistry Advances, Vol. 6, pp 91243-91249. https://doi.org/10.1039/C6RA17097H

[15] Lolla, D. - Lolla, M. - Abutaleb, A. - Shin, H. U. - Reneker, D. H. - Chase, G. G. (2016): Fabrication, Polarization of Electrospun Polyvinylidene Fluoride Electret Fibers and Effect on Capturing Nanoscale Solid Aerosols, Materials, Vol. 9, 671, pp 1-17. https://doi.org/10.3390/ma9080671

[16] Wang, L. Y. - Yong, W. F. - Yu, L. E. - Chung, T. S. (2017): Design of High Efficiency PVDF-PEG Hollow Fibers for Air Filtration of Ultrafine Particles, Journal of Membrane Sciences, Vol. 535, pp 342-349. https://doi.org/10.1016/j.memsci.2017.04.053

[17] Dargaville, R. - Celina, M. C. - Elliott, J. M. - Chaplya, P. M. - Jones, G. D. - Mowery, D. M. - Assink, R. A. - Clought, R. L. - Martin, J. W. (2005): Characterization, Performance and Optimization of PVDF as A Piezoelectric Film for Advanced Space Mirror Concepts, The United States Department of Energy, Sanda Corporation: Sandia National Laboratories, Sandia Report SAND2005-6846

[18] Matsumoto, H. - Tanioka, A. (2011): Functionality in Electrospun Nanofibrous Membranes Based on Fiber's Size, Surface Area, and Molecular Orientation, Membranes, Vol. 1, pp 249-264. https://doi.org/10.3390/membranes1030249

[19] Cho, D. - Naydich, A. - Frey, M. W. - Joo, Y. L. (2013): Further Improvement of Air Filtration Efficiency of Cellulose Filters Coated with Nanofibers via Inclusion of Electrostatically Active Nanoparticles, Polymer, Vol. 54, pp 2364-2372. https://doi.org/10.1016/j.polymer.2013.02.034_

[20] Hwang, J. - Muth, J. - Ghosh, T. (2007): Electrical and Mechanical Properties of Carbon-Black-Filled, Electrospun Nanocomposite Fiber Webs, Journal of Applied Polymer Science, Vol. 104, pp 2410-2417. https://doi.org/10.1002/app.25914

[21] Tarasova, E. - Byzova, A. - Savest, N. - Viirsalu, M. - Gudkova, V. Martson, T. - Krumme, A. (2015): Influence of Preparation Process on Morphology and Conductivity of Carbon Black-Based Electrospun Nanofibers, Fullerenes, Nanotubes and Carbon Nanostructures, Vol. 23, pp 695-700. https://doi.org/10.1080/1536383X.2014.974090

[22] Shah, J. - Jan, M. R. - Mabood, F. - Shahid, M. (2006): Conversion of Waste Tyres Into Carbon Black and Their Utilization as Adsorbent, Journal of the Chinese Chemical Society, Vol. 53, pp 1085-1089. https://doi.org/10.1002/jccs.200600144

[23] Islam, A. K. M. M. - Hwang, J. I. - Lee, S. E. - Kim, J. E. (2016): Comparative Study of Carbon Black and Activated Carbon Adsorbents for Removal of Carbofuran from Aqueous Solution, Desalination and Water Treatment, Vol. 57, pp 1-12. https://doi.org/10.1080/19443994.2015.1124053
[24] Kalluri, S. - Asha, A. M. - Parvathy, S. - Kim, T. N. - Sivakumar, N. Subramanian, K. R. V. - Nair, S. V. - Balakrishnan, A. (2013): Electrospun Nanofibers of Polyaniline-Carbon Black Composite for Conductive Electrode Applications, Trends in Polyaniline Research: Chapter 8, Nova Science Publishers, Inc

[25] Li, W. K. - Wong, Y. W. (2009): Electrical Properties of Electrospun Nanofibers of PEO/Carbon Black Composite, Solid State Phenomena, Vol. 151, pp 67-71. https://doi.org/10.4028/www.scientific.net/SSP.151.67

[26] Lawandy, S. N. - Wassef, M. T. (1990): Penetration of Oils Into Polychloroprene Rubber, Journal of Applied Polymer Science, Vol. 40, pp 323-331. https://doi.org/10.1002/app.1990.070400302

[27] Razzaz, A. - Ghorban, S. - Hosyani, L. - Irani, M. - Aliabadi, M. (2016): Chitosan Nanofibers Functionalized by $\mathrm{TiO}_{2}$ Nanoparticles for The Removal of Heavy Metal Ions, Journal of the Taiwan Institute of Chemical Engineers, Vol. 58, pp 333-343. https://doi.org/10.1016/j.jtice.2015.06.003

[28] Nasikhudin Diantoro, M. - Kusumaatmaja, A. - Triyana, K. (2016): Preparation of PVA/Chitosan/TiO 2 Nanofibers Using Electrospinning Method, AIP Conference Proceedings, Vol. 1755, 150002, pp 1-6. https://doi.org/10.1063/1.4958575

[29] Moradi, R. - Sabet, J. K. - Niassar, M. S. - Koochaki, M. A. (2015): Preparation and Characterization of Polyvinylidene Fluoride/Graphene Superhydrophobic Fibrous Films, Polymers, Vol. 7, pp 1444-1462. https://doi.org/10.3390/polym7081444

[30] Huang, S. - Yee, W. A. - Tjiu, W. C. - Liu, Y. - Kotaki, M. - Boey, Y. C. F. - Ma, J. - Liu, T. - Lu, X. (2008): Electrospinning of Polyvinylidene Difluoride with Carbon Nanotubes: Synergistic Effects of Extensional Force and Interfacial Interaction on Crystalline Structures, Langmuir, Vol. 24, pp 13621-13626. https://doi.org/10.1021/la8024183

[31] Liu, Z. H. - Pan, C. T. - Lin, L. W. - Lai, H. W. (2013): Piezoelectric Properties of PVDF/MWCNT Nanofiber Using Near-Field Electrospinning, Sensors and Actuators A: Physical, Vol. 193, pp 13-24.

https://doi.org/10.1016/j.sna.2013.01.007

$\underline{\text { Ref.: }}$

Nasir, Muhamad - Sugatri, Rana Ida - Asri, Putri Putih Puspa - Dara, Fitri - Ardeniswan: Nanostructure and Surface Characteristic of Electrospun Carbon Black/PVDF Copolymer Nanocomposite Építőanyag - Journal of Silicate Based and Composite Materials, Vol. 70, No. 6 (2018), 209-213. p. https://doi.org/10.14382/epitoanyag-jsbcm.2018.36

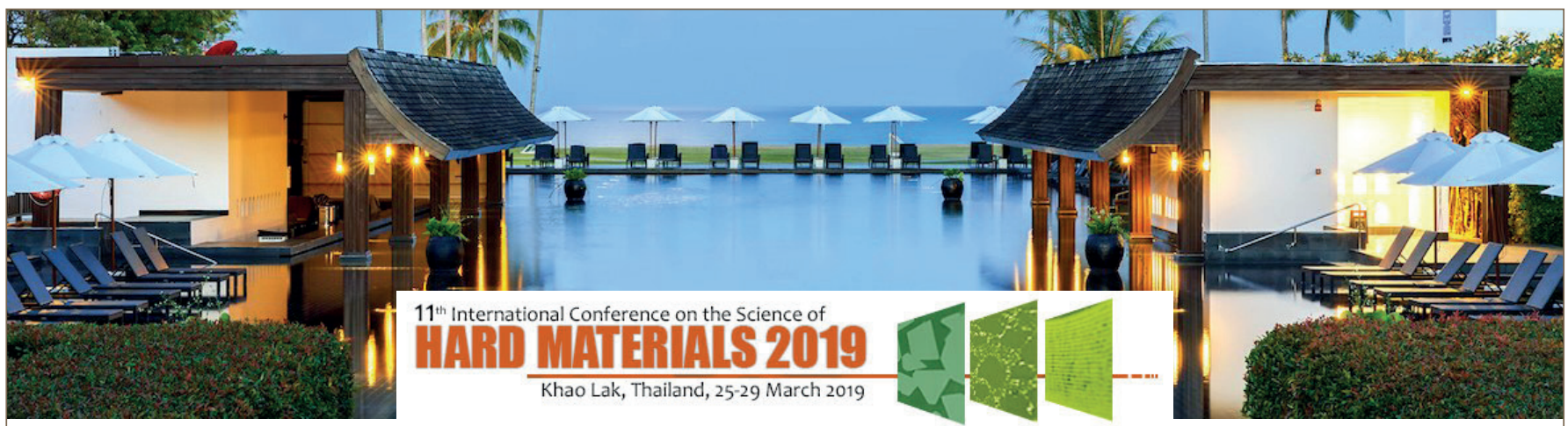

The 11th International Conference on the Science of Hard Materials (ICSHM11) attempts to bring together scientists, technologists and manufacturers of Hard Materials. This broad but unique set of materials includes technically successful and continuously evolving subgroups such as cemented carbides, cermets, advanced ceramics, composites and super-hard materials. Through the years, synergy between science and technology has catalyzed achievement of superior quality and enhanced performance of components, tools and devices of hard materials by means of innovative microstructural design at different length-scales: bulk/film, monolithic/composite, functionally graded, surface modified, and micro/nano-structures. As a consequence, the range of applications for hard materials has been growing not only within consolidated sectors such as metalworking, mining, oil- and gas-drilling, construction, process and machine building industries, but also into high-tech and emerging technologies in the electronics, aeronautics and dental sectors, among others. As it has been the tradition in the previous ten conferences, the aim of ICSHM11 will be to provide an interdisciplinary forum for presentation, discussion and exchange of modeling, experimental and applied concepts that contribute in the advancement of Hard Materials.

www.icshm11.org 